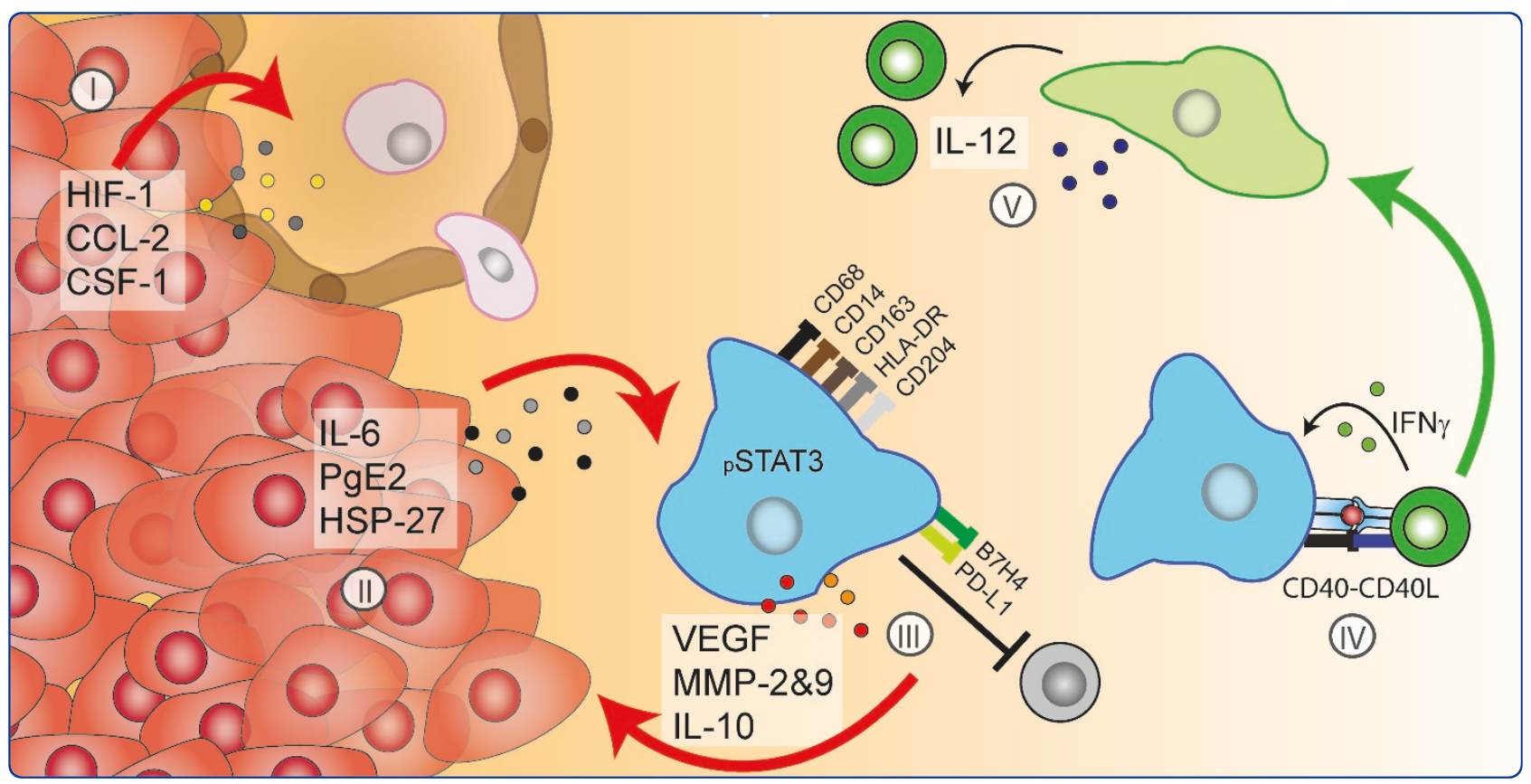

\title{
Identification and manipulation of tumor associated macrophages in human cancers
}

Heusinkveld and van der Burg 


\title{
Identification and manipulation of tumor associated macrophages in human cancers
}

\author{
Moniek Heusinkveld and Sjoerd H van der Burg ${ }^{*}$
}

\begin{abstract}
Evading immune destruction and tumor promoting inflammation are important hallmarks in the development of cancer. Macrophages are present in most human tumors and are often associated with bad prognosis. Tumor associated macrophages come in many functional flavors ranging from what is known as classically activated macrophages (M1) associated with acute inflammation and T-cell immunity to immune suppressive macrophages (M2) associated with the promotion of tumor growth. The role of these functionally different myeloid cells is extensively studied in mice tumor models but dissimilarities in markers and receptors make the direct translation to human cancer difficult. This review focuses on recent reports discriminating the type of infiltrating macrophages in human tumors and the environmental cues present that steer their differentiation. Finally, immunotherapeutic approaches to interfere in this process are discussed.
\end{abstract}

Keywords: Tumor infiltrating macrophages, M1, M2, T cells, immunotherapy

\section{Macrophages}

Macrophages are a heterogeneous population of innate myeloid cells involved in health and disease. Macrophages originate from monocytic precursors in the blood and undergo specific differentiation depending on local cues in the tissue [1]. Roughly two distinct polarization states are recognized; the classically activated type 1 macrophages (M1) and the alternative activated type 2 macrophages (M2). In response to activating danger signals delivered by bacterial products or IFN $\gamma$, macrophages adapt to a M1 phenotype which is tailormade to attract and activate cells of the adaptive immune system. Important features of M1 macrophages are the expression of iNOS, ROS and the production of NK and type 1 T-cell stimulating cytokine IL-12. M1 macrophages can phagocytose and kill target cells. M2 macrophages can develop in response to for instance IL4 or IL-13[2,3], express abundant scavenger receptors and are associated with high production of IL-10, IL-1b, VEGF and matrix metalloproteinases (MMP). M2 macrophages play a role in parasite clearance and wound healing where they also polarize $\mathrm{T}$ cells to Th2 and dampen immune responses [4]. Furthermore

\footnotetext{
* Correspondence: SHvdBurg@lumc.nl
Dept. of Clinical Oncology, Leiden University Medical Center, Leiden, The

* Correspondence: SHvdBurg@lumc.nl
Dept. of Clinical Oncology, Leiden University Medical Center, Leiden, The Netherlands
}

macrophages are antigen presenting cells (APC) that express class I and class II HLA-molecules and co-stimulatory/inhibitory molecules to instruct $\mathrm{T}$ cells, albeit with lesser efficiency than dendritic cells. Notably, the terms M1 and M2 are an oversimplification of the macrophage types that can be detected. Macrophages display great plasticity and can adapt to a plethora of activation states ranging between the M1 or M2 phenotype depending on the mix of signals in their direct microenvironment. A number of excellent reviews on this topic were recently published [2,5-7]. In addition, fully polarized M1 and M2 macrophages can be redirected in vitro towards the opposite functional phenotype by treatment of the cells with cytokines [8]. For the remainder of this review we will refer to M1 and M2 macrophages under the notion that both M1 and M2 will reflect a whole range of functional states of macrophages.

\section{ages in human tumors; clinical impact}

For long macrophages are known to play a role in the development of tumors. This has been exemplified by their depletion in a number of mouse tumor models [9]. Carcinogenesis is characteristically associated with macrophage-mediated smoldering inflammation, often 
caused by pathogens [10], or as a result of autoimmunity and inflammatory conditions of uncertain origin $[3,11]$. In human studies on cancer, macrophages have predominantly been identified by immunohistochemistry applying antibodies against CD68 (Table 1) [12-52]. Most studies suggest that a high number of tumor associated macrophages is beneficial for tumor growth and, therefore, associated with disease progression and poor prognoses for the patient (reviewed in [53]). However, sometimes a high number of infiltrating macrophages correlates with better prognosis. For instance in human papilloma virus (HPV) induced cervical intraepithelial neoplasia macrophage infiltration was reported to correlate with disease progression [23]. Yet, in cervical cancers the number of stromal macrophages positively correlated with the intratumoral expression of IL-12p40, which itself was associated with a favorable overall survival of patients [54]. In lung cancer, higher numbers of IL-10+ CD68+ macrophages correlated with poor survival of patients with late stage disease [51]. However, another study showed that high macrophage numbers correlated with better survival. Importantly, in this study the polarization of the macrophages was determined and this revealed that improved survival was associated with a high $M 1 / M 2$ ratio [37]. The type of macrophages studied thus may explain the apparent discrepancy between studies. Clearly, tumors can give rise to a heterogeneous population of tumor-infiltrating myeloid cells that differ at the molecular and functional level as a result of different instructions given by the local microenvironment [55-57]. The detection of macrophages on basis of CD68 does not allow identification of these distinct subsets and this deficit has been recognized in the field. Recent studies often show that antibodies to 2-3 different markers are combined (Table 1). Unfortunately, there are not many studies that apply the same set of markers to study the subsets of tumor-infiltrating macrophages. Furthermore, sometimes combinations of different antibodies were not used to discriminate between macrophage subsets but to differentiate between the expression of certain types of immune regulatory molecules by macrophages and tumor cells (e.g. PD-L1) [58,59]. It should be noted that the predominant detection of M2 macrophages reflects the late stage of tumor progression since the presence, type and role of macrophages in lower staged neoplasias is only marginally studied [23,60].

Alternatively, the number of tumor associated macrophages may form an epiphenomenon reflecting an inflamed tumor micro-environment in which many types of immune cells can be found $[48,61]$. This may comprise strong infiltration by regulatory $\mathrm{T}$ cells that exert a negative impact on clinical outcome. On the other hand it may also include the infiltration of tumors by $\mathrm{T}$ cells with cytotoxic function and a type 1 cytokine profile $[62,63]$. Moreover, macrophages do not only contribute to the local inflammation but also impair the activation of an effective anti-tumor $\mathrm{T}$-cell response in tumor draining lymph nodes by inducing apoptosis [64].

\section{Identification of distinct human macrophage subsets}

Macrophages can be identified by the expression of transcriptional factors, cell surface markers, the production of cytokines and their function in vitro. In humans, the detection of tissue associated monocytes and macrophages in situ, is predominantly based on the use of antibodies to the glycoprotein CD68. However, antibodies to the LPS-co receptor CD14 or to HLA class II, represented by HLA-DR, are also used. Potentially, antibodies to the Fc $\gamma$-receptors can also be used, as these receptors - used to bind antibody-bound particles - are highly expressed by macrophages. So far, only antibodies to Fc $\gamma$ RIII (CD16) have been used for the flow cytometric analysis of macrophages in vitro [65]. Newly added to the list of antibodies are those that target macrophage subset-specific markers. M2 macrophages express high levels of CD163, a hemoglobin-scavenger receptor, and can be used to discriminate between M1 and M2 macrophages (Table 1 and [66,67]). Tolerogenic macrophages and DC display higher levels of the mannose receptor (CD206) which is another scavenger [5]. In addition, the macrophage scavenging receptor 1 (CD204) is used as a specific M2 macrophage marker (Table 1). Thus far no unique markers for M1 macrophages are described. A list of markers which are currently applied to detect and distinguish between M1 and M2 macrophages is shown in table 2[5,6,29,53,67-77]. Matters, however, become more complicated when these macrophages become activated either via their pathogen-associated molecular pattern (PAMP)-receptors or upon cognate interaction with other immune cells. We and others have observed that activation results in loss of expression of the typical macrophage (e.g. CD14) and M2 markers (e.g. CD163, CD16 [65,66]). This implies that the use of a combination of different antibodies against cell surface markers to detect distinct macrophage subsets polarization will always be imperfect, albeit able to deliver much more information as in previous studies. To overcome this problem the expression of molecules that are directly related to macrophage function can be studied. Matrix metalloproteinases (MMPs) are proteolytic enzymes that degrade extracellular matrix and the basic membrane and are involved in tissue remodeling, tumor invasion and neovascularization of tumors. For instance, MMP 1, 2 and 9 are abundantly produced by M2 macrophages. The expression of MMPs in combination with CD68 or 
Table 1 Tumor associated macrophages in situ

\begin{tabular}{|c|c|c|c|c|c|c|c|}
\hline Organ & Cancer type & $\mathrm{n}^{1}$ & Method $^{2}$ & Markers & Macrophage infiltrate? & Link to prognosis ${ }^{3}$ & Ref \\
\hline \multirow[t]{3}{*}{ Lymphnode } & Hodgkins lymphoma & 265 & TMA IHC & CD68 CD163 & $\begin{array}{l}\text { Using a } 5 \% \text { of cells is positive } \\
\text { cut-off; } 80 \% \text { is CD68+ cell } \\
\text { positive and } 64 \% \text { is CD163+ }\end{array}$ & No link & 7 \\
\hline & Hodgkins lymphoma & 130 and 166 & $\mathrm{HHC}$ & CD68 MMP11 & $\begin{array}{l}\text { Using a } 5 \% \text { and } 1 \% \text { of cells is } \\
\text { positive cut-off; } 72 \% \text { is CD68+ } \\
\text { cell positive and } 41 \% \text { positive } \\
\text { for MMP- } 11\end{array}$ & $\begin{array}{l}\text { High CD68+ MF or high } \\
\text { MMP-11 expression } \\
\text { correlates with poor } \\
\text { disease specific survival }\end{array}$ & 40 \\
\hline & Hodgkins lymphoma & 105 & TMA IHC & CD68 & $\begin{array}{l}42 \% \text { has high MF infiltration (> } \\
0,82 \% \text { of total cells is positive } \\
\text { for CD68) }\end{array}$ & $\begin{array}{l}\text { High infiltration } \\
\text { correlates with higher } \\
\text { age and poor survival } \\
\text { (also in the younger } \\
\text { patients) }\end{array}$ & 42 \\
\hline \multirow[t]{6}{*}{ Colon } & CRC & 17 & $\mathrm{HHC}$ & CCL2 CD68 IL-8 & $\begin{array}{l}\text { Mean MF number in tumor } 8 / \\
\mathrm{mm} 3 \text {, in stroma } 44 / \mathrm{mm} 3 \text { and } \\
\text { necrotic area's } 44 / \mathrm{mm} 3 \text { and all } \\
\text { tumors are high IL-8 postive }\end{array}$ & $\begin{array}{l}\text { Tumor cell produced } \\
\text { CCL2 correlates to MF } \\
\text { count and advanced } \\
\text { disease stage }\end{array}$ & 8 \\
\hline & CRC & 478 & $\mathrm{HHC}$ & CD68 & $\begin{array}{l}76 \% \text { has high MF infiltration at } \\
\text { tumor front }\end{array}$ & $\begin{array}{l}\text { High MF count at } \\
\text { tumorfront associates } \\
\text { with better prognosis }\end{array}$ & 16 \\
\hline & CRC & 118 & $\mathrm{HCC}$ & $\begin{array}{l}\text { CD68 MMP-2 } \\
\text { MMP-9 }\end{array}$ & $\begin{array}{l}47 \% \text { has high MF numbers and } \\
\text { this correlates with expression } \\
\text { of MMP- } 2 \text { and MMP-9 }\end{array}$ & $\begin{array}{l}\text { Intratumoral TAM } \\
\text { correlate with invasion, } \\
\text { LN status and staging }\end{array}$ & 21 \\
\hline & CRC & 40 & $\mathrm{DIHC}$ & $\begin{array}{l}\text { CD68 S100 } \\
\text { CD163 }\end{array}$ & $\begin{array}{l}\text { In all samples MF infiltration, } \\
\text { more in stroma than in tumor } \\
\text { beds. Mean is } 12 / 15 \text { per high } \\
\text { power field. }\end{array}$ & $\begin{array}{l}\text { Significant better } \\
\text { survival for patient with } \\
\text { high DC count and } \\
\text { trend for high CD163 } \\
\text { count. }\end{array}$ & 29 \\
\hline & CRC & 159 & $\mathrm{HHC}$ & $\begin{array}{l}\text { CD68 Clever-1/ } \\
\text { Stabilin-1 CD206 } \\
\text { CD3+ }\end{array}$ & $\begin{array}{l}\text { 98\% has peritumoral } \\
\text { macrophages in } 10 \text { tested } \\
\text { tumors all MF are CD206/ } \\
\text { Clever-1 dubbelpositive }\end{array}$ & $\begin{array}{l}\text { High peritumoral CD68 } \\
\text { better prognosis; low } \\
\text { intratumoral M1/M2 } \\
\text { ratio more recurrent } \\
\text { disease }\end{array}$ & 52 \\
\hline & $\begin{array}{l}\text { CRC metastasis in } \\
\text { liver }\end{array}$ & 15 & $\mathrm{HHC}$ & $\begin{array}{l}\text { CD68 CD163 } \\
\text { CXCL-10 CXCR-4 } \\
\text { CXCL-12 Her1 } \\
\text { Her4 HB-EGF }\end{array}$ & $\begin{array}{l}\text { CD68, CXCL-10, CD163 positive } \\
\text { cells are found in al lesions }\end{array}$ & - & 35 \\
\hline \multirow[t]{2}{*}{$\begin{array}{l}\text { Intestinal } \\
\text { tract }\end{array}$} & GIST & $\begin{array}{l}47 \text { ( } 19 \\
\text { metastatic) }\end{array}$ & $\mathrm{FIHC}$ & $\begin{array}{l}\text { CD68 CD163 } \\
\text { CD14 CD1a CD20 } \\
\text { S100, HLA-DR } \\
\text { CD3 CD8 FoxP3 } \\
\text { CD33 }\end{array}$ & $\begin{array}{l}\text { High infiltrate in primary lesion } \\
\text { tumors }(2,7 \%) \text { and metastatic } \\
\text { lesions }(4,9 \%) \text { of CD163+ } \\
\text { macrophages. }\end{array}$ & $\begin{array}{l}\text { Presence of } \mathrm{M} 2 \text { is } \\
\text { correlated with FoxP3 } \\
\text { positive infiltrate }\end{array}$ & 43 \\
\hline & gastric cancer & 105 & $\mathrm{IHC} Z \mathrm{G}$ & $\begin{array}{l}\text { hypoxia CD68 } \\
\text { CD34 VEGF } \\
\text { MMP2 +9 }\end{array}$ & $\begin{array}{l}\text { More macrophages in hypoxic } \\
\text { area's }\end{array}$ & $\begin{array}{l}\text { Hypoxia and more } \\
\text { macrophages correlates } \\
\text { with shorter survival }\end{array}$ & 34 \\
\hline \multirow[t]{4}{*}{ Lung } & NSCLC & 100 & $\mathrm{DIHC}$ & $\begin{array}{l}\text { CD68 HLA-DR } \\
\text { CD163 }\end{array}$ & $\begin{array}{l}\text { Of CD68 positive MF } 70 \% \\
\text { express CD163, 3\% is positive } \\
\text { for CD163 and HLA-DR }\end{array}$ & $\begin{array}{l}\text { Patients with long } \\
\text { survival have higher } \\
\text { number of M1 type MF }\end{array}$ & 28 \\
\hline & $\mathrm{NSCLC}$ & 50 & $\mathrm{DIHC}$ & CD68 IL-10 & $\begin{array}{l}95 \% \text { of IL-10 positive cells in } \\
\text { advancing tumor margin is of } \\
\text { MF origin }\end{array}$ & $\begin{array}{l}\text { High IL-10 positive MF } \\
\text { in advanced disease and } \\
\text { therefore correlated to } \\
\text { poor prognosis }\end{array}$ & 46 \\
\hline & $\mathrm{NSCLC}$ & 40 & $\mathrm{HHC}$ & $\begin{array}{l}\text { CD68 DR CD163 } \\
\text { VEGF TNFa iNOS, }\end{array}$ & $\begin{array}{l}\text { Less MF infiltrate in tumor } \\
\text { islets of patient with shorter } \\
\text { survival (all MF types) }\end{array}$ & $\begin{array}{l}\text { More MF in tumor islets } \\
\text { correlate with better } \\
\text { prognosis }\end{array}$ & 32 \\
\hline & $\mathrm{NSCLC}$ & 20 & $\mathrm{HHC}$ & $\begin{array}{l}\text { CXCR-1,2,3,4,5 } \\
\text { and CCL-1 }\end{array}$ & $\begin{array}{l}\text { CXCR-3 is positively correlated } \\
\text { with MF number as } \\
\text { determined in (ohri ERJ 2009) }\end{array}$ & $\begin{array}{l}\text { Higher CXCR-2, CXCR-3 } \\
\text { and CCL-1 expression in } \\
\text { patients with extended } \\
\text { survival }\end{array}$ & 33 \\
\hline
\end{tabular}


Table 1 Tumor associated macrophages in situ (Continued)

\begin{tabular}{|c|c|c|c|c|c|c|c|}
\hline Mesothelioma & $\begin{array}{l}\text { pleural } \\
\text { mesothelioma }\end{array}$ & $\begin{array}{l}52(+7 \\
\text { flowcytometry) }\end{array}$ & $\mathrm{HC}$ & $\begin{array}{l}\text { CD68 CD163 } \\
\text { CD206 CD124 }\end{array}$ & $\begin{array}{l}\text { CD68+ MF comprised } 27 \% \text { of } \\
\text { tumor area, } 7 \text { tumors tested by } \\
\text { flowcytometry; MF express } \\
\text { high levels of M2 markers }\end{array}$ & $\begin{array}{l}\text { High MF number in } \\
\text { non-epithelial tumors is } \\
\text { associated with bad } \\
\text { prognosis }\end{array}$ & 10 \\
\hline \multirow[t]{2}{*}{ Breast } & breast CA & $110+106$ & $\mathrm{HCC}$ & $\begin{array}{l}\text { CD68 anti-PCNA } \\
\text { (proliferation) }\end{array}$ & $\begin{array}{l}\text { Double positive proliferating } \\
\text { macrophages are found in } \\
\text { most tumors }\end{array}$ & $\begin{array}{l}\text { High number of } \\
\text { proliferating } \\
\text { macrohpages associated } \\
\text { with decreased survival }\end{array}$ & 12 \\
\hline & breast CA & 127 & $\mathrm{IHC}$ & $\begin{array}{l}\text { CD68 CD163 } \\
\text { MAC387 }\end{array}$ & $\begin{array}{l}\text { Using a } 25 \% \text { surface area } \\
\text { cut0off; } 48 \% \text { has high } \\
\text { infiltration of CD163+ cells, } \\
\text { MAC387 expression in } 12 \%\end{array}$ & $\begin{array}{l}\text { High CD163 correlates } \\
\text { with more distant } \\
\text { disease recurrence }\end{array}$ & 38 \\
\hline $\begin{array}{l}\text { Breast and } \\
\text { Colon }\end{array}$ & $\begin{array}{l}\text { primairy metastatic } \\
\text { lesions }\end{array}$ & $\begin{array}{l}49 \text { breast and } \\
12 \text { colon } \\
\text { metastasis }\end{array}$ & $\mathrm{HCC}$ & $\begin{array}{l}\text { FC } \gamma R \text { Rllla, FC } \gamma \text { RII, } \\
\text { CTSL1, CD163 }\end{array}$ & $\begin{array}{l}\text { Signature in primary lesion is } \\
\text { the same as in corresponding } \\
\text { metastatic lymphenode }\end{array}$ & - & 44 \\
\hline \multirow[t]{4}{*}{$\begin{array}{l}\text { Ovarian and } \\
\text { Peritoneum }\end{array}$} & ovarium carcinoma & & $\begin{array}{l}\mathrm{MS} \\
\mathrm{DIHC/} \\
\mathrm{FHCC}\end{array}$ & $\begin{array}{l}\text { levels of } \\
\text { eicosanoids } \\
\text { (PGE2) and other } \\
\text { related enzymes }\end{array}$ & $\begin{array}{l}\text { High levels of eicosanoids in } \\
\text { tumors, peritumoral CD163+ } \\
\text { MF express COX and PGES }\end{array}$ & - & 17 \\
\hline & $\begin{array}{l}\text { epithelial ovarian } \\
\text { carcinoma }\end{array}$ & $\begin{array}{l}40 \text { (21 serous, } \\
19 \text { mucinous) }\end{array}$ & $\mathrm{HC}$ & $\begin{array}{l}\text { CD68 CD163 } \\
\text { CD204 CSF-1 }\end{array}$ & $\begin{array}{l}\text { M2 cells present in stomal } \\
\text { compartment of all patients, } \\
\text { MF number and CSF-1 increase } \\
\text { with disease progression }\end{array}$ & $\begin{array}{l}\text { High M2 correlates with } \\
\text { disease stage }\end{array}$ & 22 \\
\hline & ovarium CA & $60+12$ & $\begin{array}{l}\text { FIHC } \\
\text { DIHC } \\
\text { Flow }\end{array}$ & $\begin{array}{l}\text { B7-H4 HAM56 } \\
\text { CD3 }\end{array}$ & $\begin{array}{l}70 \% \text { of intratumoral MF } \\
\text { express } \mathrm{B} 7-\mathrm{H} 4\end{array}$ & - & 24 \\
\hline & ovarium CA & 103 & $\mathrm{DIHC}$ & $\begin{array}{l}\text { B7H4 HAM56 } \\
\text { (CD4 FoxP3) }\end{array}$ & $\begin{array}{l}\text { Higher expression of B7-H4 on } \\
\text { macrophages in advanced } \\
\text { stage and correlate with the } \\
\text { presence of regulatory T cells. }\end{array}$ & $\begin{array}{l}\text { High B7-H4 expression } \\
\text { on MF correlates with } \\
\text { poor survival }\end{array}$ & 25 \\
\hline \multirow[t]{2}{*}{ Uterus } & $\begin{array}{l}\text { endometrioid } \\
\text { carcinoma }\end{array}$ & 64 & $\mathrm{IHC}$ & $\begin{array}{l}\text { CD163 CD31 HIF- } \\
1 \mathrm{~A}\end{array}$ & $\begin{array}{l}\text { Only invasive tumors have } \\
\text { high MF infiltration, more } \\
\text { HIF1A and higher vessel } \\
\text { density }\end{array}$ & $\begin{array}{l}\text { In paired LN metastatic } \\
\text { lesion same pattern for } \\
\text { CD163 and CD31 is } \\
\text { found }\end{array}$ & 14 \\
\hline & $\begin{array}{l}\text { endometrioid adeno } \\
\text { CA }\end{array}$ & 61 & $\mathrm{IHC}$ & MMP-12 en CD68 & $\begin{array}{l}\text { Higher MF and MMP-12 } \\
\text { expression in more advanced } \\
\text { disease }\end{array}$ & $\begin{array}{l}\text { Higher MMP-12 and MF } \\
\text { in advanced disease }\end{array}$ & 45 \\
\hline Cervix & $\mathrm{CIN}, \mathrm{HSIL}, \mathrm{CxCa}$ & 86 & $\mathrm{IHC}$ & CD68 & $\begin{array}{l}\text { Number of MF correlates with } \\
\text { disease progression }\end{array}$ & $\begin{array}{l}\text { High MF number } \\
\text { predicts disease } \\
\text { progression }\end{array}$ & 18 \\
\hline \multirow[t]{2}{*}{ Skin } & stage $1 / 2$ melanoma & $\begin{array}{l}227 \text { blood } 190 \\
\text { tumors }\end{array}$ & $\begin{array}{l}\text { IHC } \\
\text { ELISA }\end{array}$ & $\begin{array}{l}\text { CD68 CD163 and } \\
\text { soluble CD163 }\end{array}$ & $\begin{array}{l}67 \% \text { has dense infiltration with } \\
\text { CD163 cells at invasive front } \\
\text { and stroma }\end{array}$ & $\begin{array}{l}\text { High CD163 in tumor } \\
\text { front or stroma } \\
\text { correlates with poor } \\
\text { survival }\end{array}$ & 20 \\
\hline & $\begin{array}{l}\text { metastatic } \\
\text { melanoma }\end{array}$ & 6 & $\mathrm{FIHC}$ & $\begin{array}{l}\text { CD45 CD68 } \\
\text { CD163 CD209 } \\
\text { CXCL-12 }\end{array}$ & $\begin{array}{l}60 \% \text { of perivascular TAM } \\
\text { expres CXCL-12 }\end{array}$ & - & 37 \\
\hline \multirow[t]{2}{*}{ Prostate } & $\begin{array}{l}\text { first diagnostic } \\
\text { screening; }\end{array}$ & $\begin{array}{l}92 \text { of which } \\
30 \% \text { has } \\
\text { prostate ca }\end{array}$ & $\mathrm{IHC}$ & CD68 CD204 & $\begin{array}{l}\text { Less CD204 positive cells is } \\
\text { associated with development } \\
\text { of prostate CA }\end{array}$ & - & 31 \\
\hline & $\begin{array}{l}\text { needle biopsies } \\
\text { prostate }\end{array}$ & 135 & $\mathrm{IHC}$ & CD204 & $\begin{array}{l}\text { CD204 positive cells present in } \\
\text { all samples }\end{array}$ & - & 41 \\
\hline Eye & eye melanoma & 43 & $\mathrm{FIH}$ & CD68 CD163 & $\begin{array}{l}\text { Most MF are double positive, } \\
\text { more macrophages in } \\
\text { monosomy of chromosome } 3\end{array}$ & $\begin{array}{l}\text { Less macrohpages is } \\
\text { associated with better } \\
\text { survival }\end{array}$ & 9 \\
\hline Kidney & renal cell carcinoma & 43 & $\mathrm{DHH}$ & $\begin{array}{l}\text { CD209 CD14 } \\
\text { CD163 }\end{array}$ & $\begin{array}{l}\text { Most CD209+ cells were also } \\
\text { CD14 and CD163+ }\end{array}$ & - & 15 \\
\hline Liver & $\begin{array}{l}\text { hepatocellular } \\
\text { carcinoma }\end{array}$ & 63 & $\mathrm{IHC}$ & $\begin{array}{l}\text { CD68 B7-H1 (PD- } \\
\text { L1) }\end{array}$ & $\begin{array}{l}\text { High } \mathrm{B} 7-\mathrm{H} 1 \text { expression on } \\
\text { tumorcells if high macrophage } \\
\text { infiltration ( } 48 \% \text { of patients) }\end{array}$ & - & 13 \\
\hline
\end{tabular}


Table 1 Tumor associated macrophages in situ (Continued)

\begin{tabular}{|c|c|c|c|c|c|c|c|}
\hline & $\begin{array}{l}\text { intra-hepatic } \\
\text { cholangiocarcinoma }\end{array}$ & 39 & $\mathrm{HHC}$ & $\begin{array}{l}\text { CD68 CD163 } \\
\text { CD34 FoxP3 }\end{array}$ & $\begin{array}{l}50 \% \text { of patients has high } \mathrm{M} 2 \\
\text { infiltration and this correlates } \\
\text { with vessel density and FoxP3+ } \\
\text { numbers }\end{array}$ & $\begin{array}{l}\text { High CD163+ correlates } \\
\text { to poor disease free } \\
\text { survival }\end{array}$ & 19 \\
\hline Brain & glioma & 79 & $\mathrm{DIHC}$ & $\begin{array}{l}\text { CD68 CD163 } \\
\text { CD204 M-CSF }\end{array}$ & $\begin{array}{l}\text { Higher macrophage infiltration } \\
\text { and shift towards M2 type in } \\
\text { advanced stage }\end{array}$ & $\begin{array}{l}\text { More CD163+CD204+ } \\
\text { macrophages and high } \\
\text { M-CSF in advanced } \\
\text { stages }\end{array}$ & 23 \\
\hline Pancreas & $\begin{array}{l}\text { pancreatic head } \\
\text { cancer invasive } \\
\text { ductal cancer }\end{array}$ & 76 & $\mathrm{DIHC}$ & $\begin{array}{l}\text { CD68 CD163 } \\
\text { CD204 }\end{array}$ & $\begin{array}{l}42 \% \text { shows high } M 2 \text { infiltration } \\
\text { perivasculair in invasive front }\end{array}$ & $\begin{array}{l}\text { High M2 infiltration } \\
\text { associated with LN } \\
\text { metastasis }\end{array}$ & 26 \\
\hline Soft tissues & leiomyosarcoma & $\begin{array}{l}76 \\
\text { gynecologic } \\
\text { and } 73 \text { non- } \\
\text { gynaecologic }\end{array}$ & TMA IHC & CD68 CD163 & $\begin{array}{l}44 \% \text { of patients has dense } \\
\text { infiltrate with CD163+ cells }\end{array}$ & $\begin{array}{l}\text { In non-gynecologic } \\
\text { tumors, high CD163+ } \\
\text { number correlate with } \\
\text { poor prognosis }\end{array}$ & 27 \\
\hline $\begin{array}{l}\text { Peripheral } \\
\text { Lymphoma }\end{array}$ & $\begin{array}{l}\text { angioimmunoblastic } \\
\mathrm{T} \text { cell lymphoma }\end{array}$ & 42 & $\mathrm{DIHC}$ & CD68 CD163 & $\begin{array}{l}\text { Only invasive tumors have } \\
\text { high MF infiltration, more } \\
\text { HIF1A and higher vessel } \\
\text { density }\end{array}$ & $\begin{array}{l}\text { CD163/CD68 ratio } \\
\text { correlates to overall } \\
\text { survival }\end{array}$ & 30 \\
\hline \multirow[t]{2}{*}{ Thyroid } & anaplastic carcinoma & 27 & $\mathrm{HHC}$ & $\begin{array}{l}\text { NOX-2 P22-phox } \\
\text { CD68 CD163 }\end{array}$ & $\begin{array}{l}\text { All tumors display a very dense } \\
\text { network of TAM, 57\% of tumor } \\
\text { is TAM }\end{array}$ & - & 11 \\
\hline & thyroid cancer & $\begin{array}{l}\text { well/poor/ } \\
\text { anaplastic 33/ } \\
37 / 20\end{array}$ & $\mathrm{HHC}$ & CD68 CD163 & $\begin{array}{l}\text { 27/54/95\% has high CD } 68 \\
\text { macrophage infiltrate thus } \\
\text { more macrophage in advanced } \\
\text { stage }\end{array}$ & - & 36 \\
\hline Salivary gland & salivary gland & 35 & $\mathrm{HHC}$ & $\begin{array}{l}\text { CD68 CD34 } \\
\text { VEGFa }\end{array}$ & $\begin{array}{l}\text { High infiltration with CD68 in } \\
50 \% \text { of patients }\end{array}$ & - & 39 \\
\hline
\end{tabular}

1. Number of patients analyzed

2. $\mathrm{TMA}=$ Tissue Micro Array, $\mathrm{IHC}=$ immunohistochemistry, $\mathrm{DIHC}=$ double staining for immunohistochemistry, FIHC=fluorescent immunohistochemisty staining, $\mathrm{ZG}=$ zymography $\mathrm{MS}=$ mass-spectometry, Flow=Flowcytometry

3. Macrophage infiltrate was correlated to survival, - = not conducted

CD163 has been used to visualize M2 macrophages in tumors (Table 1). The functional activity of M1 macrophages is characterized by the production of reactive oxygen species (ROS) and nitric oxide (NO). However, due to their short life-span and therefore enzymatic activity these molecules are hard to detect. Instead, the detection of with this function associated enzymes like the inducible nitric oxide synthase (iNOS) is used in some of the studies (Table 1).

In contrast to studies on macrophages in situ it is easier to assess macrophage function in vitro. All macrophages can phagocyte particles and apoptotic cells. Upon activation M1 macrophages will respond with an oxidative burst by the production of ROS and NO via iNOS as well as by the release of interleukin-12, known for its type $1 \mathrm{~T}$-cell polarizing capacity. The use of $\mathrm{NO}$ to identify human M1 macrophages is somewhat debated as it was not detected in human macrophage cultures but abundantly found in tissues as detected by IHC (reviewed [72]). Therefore, in vitro studies on human macrophages focus mostly on the production of IL-12 and IL-10 to discriminate between M1 and M2 subsets $[66,67,78,79]$.
New markers that may assist to discriminate M1 from M2 macrophages are typical transcription factors expressed by these cells [80]. M1 cells highly express IRF-5, a transcription factor that is involved in stimulating the production of type 1 interferon while repressing the production of IL-10. Forced expression of IRF-5 in M2 macrophages switches them to M1 macrophages. Genetic polymorphisms that induce overexpression of IRF-5 mRNA in human auto-immune pathologies like SLE and multiple sclerosis illustrate the link between high IRF-5 expression and type 1 inflammation in human beings (reviewed in $[81,82]$ ). Secondly, the signal transducer and activator of transcription (STAT) protein family is associated with the function of immune cells. Cytokine induced phosphorylation and nuclear expression of STAT1 is associated with a type 1 pro-inflammatory phenotype whereas STAT3 resembles an antiinflammatory phenotype. STAT3 expression is often found in tumors and tumor-infiltrating macrophages and is induced by IL-6 and IL-10 [77].

Last but not least, macrophages produce chemokines to attract other immune cells and the type of these chemokines may offer help to distinguish between the 
Table 2 Markers used to identify human tumor associated macrophages

\begin{tabular}{|c|c|c|c|c|c|c|c|c|}
\hline \multirow[t]{2}{*}{ Molecule } & \multirow[t]{2}{*}{ Function } & \multirow[t]{2}{*}{ in situ $^{1}$} & \multirow[t]{2}{*}{ in vitro ${ }^{2}$} & \multicolumn{4}{|c|}{ Expression $^{3}$} & \multirow[b]{2}{*}{ ref } \\
\hline & & & & monocytes & M1 & M2 & other & \\
\hline CD68 & Glycoprotein for adherence & $\mathrm{IHC}$ & & $x$ & $x$ & $x$ & & 53 \\
\hline CD14 & LPS co-receptor & $\mathrm{IHC}$ & Flow & $x$ & $x$ & $x$ & & 67.73 \\
\hline CD163 & Scavenger receptor hemoglobulin & $\mathrm{IHC}$ & Flow & $+/-$ & $+/-$ & $x x$ & & $5,63,75,76$ \\
\hline CD206 & Mannose receptor & & Flow & & $x$ & $x x$ & & 6 \\
\hline MMP-2 & Matrix metalloproteinase & $\mathrm{IHC}$ & Digestion & & & $x$ & Tumor cells & 70 \\
\hline MMP-9 & Matrix metalloproteinase & $\mathrm{IHC}$ & Digestion & & & $x$ & Tumor cells & 70 \\
\hline HLA-DR & Antigen presentation molecule & $\mathrm{IHC}$ & Flow & $x$ & $x$ & $x$ & Immune cells & \\
\hline CD204 & Macrophage scavenger receptor 1 & $\mathrm{IHC}$ & & & $x$ & $x$ & Tumor cells & 71 \\
\hline $\mathrm{B} 7 \mathrm{H} 4$ & Inhibiting costimulatory molecule & $\mathrm{IHC}$ & Flow & & & $x$ & Tumor cells & 29 \\
\hline CD11b & Mac-1 & & Flow & $x$ & $x$ & $x$ & & 73.76 \\
\hline $\mathrm{FRb}$ & Folate receptor beta & & Flow & & & $x$ & & 74 \\
\hline STAT-3 & Transcription factor & $\mathrm{IHC}$ & Flow & & & $x$ & Tumor tissue & 77 \\
\hline iNOS & Nitric Oxide Synthase & $\mathrm{IHC}$ & & & $x$ & & & 72 \\
\hline IL-12p70 & Interleukin & $\mathrm{IHC}$ & ELISA & $x$ & $x x$ & & & 67.69 \\
\hline IL-10 & Interleukin & $\mathrm{IHC}$ & ELISA & $x$ & $x$ & $x x$ & Tumorcells & 67 \\
\hline
\end{tabular}

1. $\mathrm{IHC}=$ Immunohistochemical staining

2. Flow = immunofluorescent flowcytometry, ELISA = Enzyme-Linked Immunosorbent Assay, Digestion = collagen digestion assay

3. $X=$ present on cell subset, $X X=$ highly expressed or produced

macrophage subsets. For example, activated M1 macrophages produce CXCL-10 (IP-10) in order to attract CD8 and Th1 CD4+ T cells. M2 macrophages attract immune cells by the production of CCL-22 and CCL18. Differentiation between human M1 and M2 macrophages on the basis of their chemokine production has so far only been evaluated in vitro $[18,79]$. In vivo, most studies focused on the total tumor-derived chemokinome and, therefore, the exact role of macrophage-produced chemokines to attract immune cells is not clear yet.

It has to be said that there are a number of reports suggesting that also tumor cells and monocytes might express CD163, the detection of which depends on the antibody that is used $[43,68]$. Furthermore, MMPs are reported to be produced by tumors as well [50]. MMPs are thought to contribute to tumor progression, however, there is accumulating evidence that MMPs may also confer tumor protection [70]. In our opinion, careful assessment of macrophages in the tumor requires preferably the use of 3 markers to identify macrophages and their functional profile.

\section{Induction of tumor associated macrophages}

Tumors require nutrients, oxygen and the ability to discharge metabolic waste and carbon dioxide. These needs are addressed by tumor associated neovascularization [11]. Macrophages are the perfect help in this process, especially the wound-healing subset, since they are equipped to remodel tissue and produce VEGF. How tumors attract these myeloid cells has been excellently reviewed before [83].
CCL-2 produced by tumor cells and tumor associated cells attracts and shapes myeloid cells and interferes with osteoclasts in bone- metastatic disease [84,85]. Blocking CCL-2 reduced the number of tumor-infiltrating macrophages in pre-clinical animal studies. Secondly, the transcription factor Hypoxia Inducible Factor-1 (HIF-1), highly expressed under hypoxic conditions, regulates the attraction of monocytes and macrophages into the tumor amongst others by induction of Colony Stimulating Factor-1 (CSF-1/M-CSF) [83].

Many studies have been conducted to determine which factors induce macrophage differentiation upon arrival in the tumor. The levels of several cytokines were measured in tumor fluids, in ascites or in blood. Furthermore, the gene expression profiles of tumor cells have been analyzed. Interleukin-6 (IL-6) was often reported to be present in tumor fluids and was a produced by many tumor derived cell lines. IL-6 is a cytokine involved in chronic inflammatory diseases such as rheumatoid arthritis [86]. A number of studies on the in vitro differentiation of M2 macrophages - when monocytes or immature DC are exposed to tumor cell supernatant derived from lung, ovarian or cervical cancer cell lines - showed that this differentiation depended on IL6 . In nearly all cases IL-6 was shown to act in synergy with other factors $[66,78,79,84,87]$. Binding of IL-6 to its receptor results in activation of STAT3 in immune cells and consequently in the suppression of immune mediators that activate the immune response [77].

CSF-1 (M-CSF) mediates, besides being a chemo attractant, the differentiation of monocytes into CD14 
+CD163+CD206high M2 macrophages in vitro [67]. A similar dual role has been suggested for VEGF which acts as an angiogenic factor when secreted by wound healing macrophages but which can also impair APC differentiation when secreted by tumor cells [88].

The inflammation-inducible cyclo-oxygenase-2 (COX2)-derived prostaglandin E2 (PGE2) is overexpressed by several human tumor-types [89]. The role of COX and PGE2 in oncogenesis has been well investigated in colorectal cancer. Blocking this pathway prevented oncogenesis in the low-intestines [90]. In vitro the addition of PGE2 to IL-4/GM-CSF stimulated monocytes skews their differentiation towards M2 macrophages $[66,78,91,92]$. Notably, overexpression of COX-2 in human lung cancer cells resulted in the production of IL- 6 and the subsequent phosphorylation of STAT3. This rendered the tumor cells more resistant to apoptosis as well as increased their VEGF production [93].

Human tumors express and release high levels of Heat Shock Protein 27 (HSP27) (reviewed by [94]). The addition of soluble HSP27 to monocytes in vitro directed their differentiation to macrophages with an immune tolerizing and proangiogenic phenotype [95].

Thus, inflammatory mediators attract myeloid cells to the tumor and direct their differentiation towards tumor promoting macrophages (Figure 1). The macrophage in the tumor tissue is subject to local levels of many factors that lead to a great variety in myeloid cell subsets even within a single tumor. Interestingly, most described factors are also produced by macrophages suggesting a feed forward loop.

\section{Macrophages and adaptive immune cells in cancer}

The plasticity of macrophages has been shown in vitro but whether M2 macrophages can revert to M1 and vice verse within the tumor environment is an emerging question. In vitro, exposure of murine macrophages to a type 1 cytokine environment skews them towards M1 macrophages. In contrast, the macrophages adapted a M2 phenotype upon exposure to IL-10 $[8,96]$. Adaptation to a particular phenotype was reversible by subsequent changes of the cytokine milieu [96]. Also human macrophages show great plasticity with respect to macrophage phenotype following stimulation with antior pro-inflammatory stimuli [97]. IFN $\gamma$, which was originally called macrophage activating factor, plays a major role in the differentiation towards M1 macrophages. It's produced by both innate and adaptive immune effector cells, including CD8 T cells and several

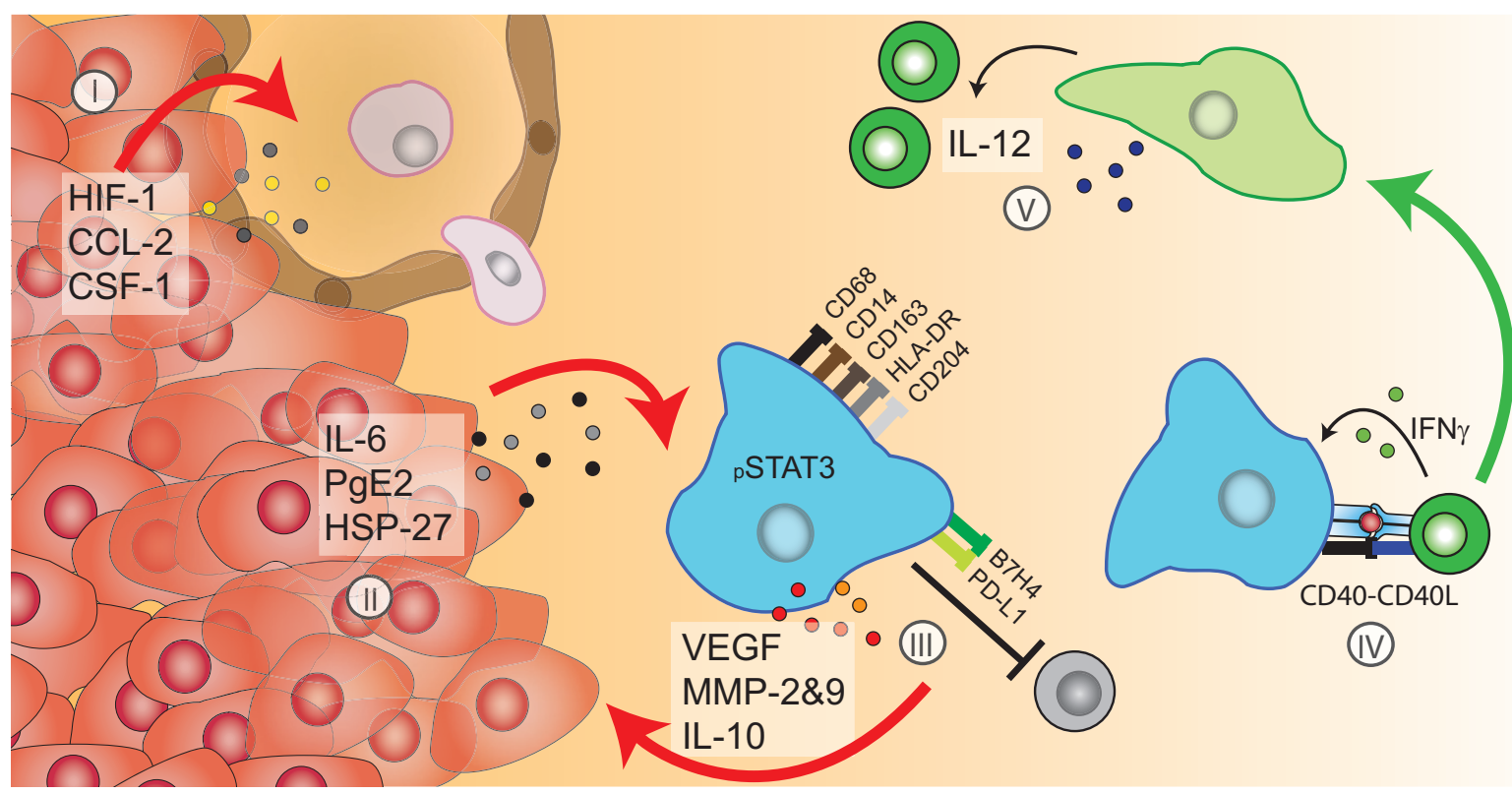

Figure 1 Macrophages and T cells in the tumor micro milieu. Tumors actively attract myeloid cells by the secretion of chemokines which is amongst others driven by hypoxia (I). Once myeloid cells have arrived in the tumor micro milieu several tumor cell produced factors drive the differentiation into a range of different types of macrophages, including M2 macrophages as a consequence of high STAT3 phosphorylation (II). M2 macrophages produce tumor promoting factors, express inhibitory molecules and upon activation produce anti-inflammatory cytokines and metalloproteinase that hamper T-cell function and promote tumor growth (III). Activation of M2 macrophages in the presence of IFN $\gamma$ - for instance following cognate interaction CD4+ type 1 helper T cells - switch M2 macrophages to pro-inflammatory activated M1 macrophages (IV). M1 macrophages alter the immune suppressed micro milieu by producing IL-12 helping anti-tumor $T$ cells as well as directly attack tumor cells ( $\mathrm{V}$ ). 
subsets of CD4 T cells, NK cells as well as $\gamma \delta \mathrm{T}$ cells. IFN $\gamma$ induces STAT1 and IRF-5 signaling-mediated type 1 cytokine production. Dulluc et al. comprehensively showed that IFN $\gamma$ can prevent and reverse the M2-skewing effect of ascites from patients with ovarian cancer. Furthermore, pre-treatment of M2 macrophages with IFN $\gamma$ results in a macrophage type that produces more IL-12 and less IL-10 upon activation with several innate stimuli [79].

Cognate interaction with CD4+ helper T cells constitutes a powerful activation signal for antigen presenting cells. The signal is delivered via CD40-CD40L interaction following T-cell receptor mediated MHC class IIpresented antigen recognition. CD40L and IFN $\gamma$ can activate in synergy but do not have to come from the same CD4 T cell. Exposure of APC to IFN $\gamma$-producing CD8+ T cells and CD40-L+ CD4 T cells allows APC to produce IL-12 and to become strong promoters of Th1 responses $[98,99]$. We showed recently that tumor skewed IL10-producing M2 macrophages can fully revert to IL12-producing M1 macrophages following interaction with CD4+ Th1 cells or with CD40-Lexpressing cells in the presence of IFN $\gamma$ [66]. Notably, in this in vitro study CD40-CD40L interaction resulted only in a strong activation signal for macrophages that was required but not sufficient to change the macrophage subset. Interestingly, we have observed that a minor population of tumor-infiltrating human CD8+ T cells expresses CD40-L upon activation [100]. This poses the question whether certain populations of intratumoral CD8 T cells can mediate the same effect on macrophages as CD4+ Th1 cells. The important role of $\mathrm{T}$ cells in instructing APC is further supported by studies showing that freshly isolated and activated bloodderived regulatory $\mathrm{T}$ cells skewed monocytes to M2 macrophages, which were able to produce high levels of IL-10 when stimulated with LPS [101]. The regulatory T cells, defined as CD4+CD25high cells, exerted their effect via the secretion of IL-13, IL-4 and most importantly IL-10 that was produced upon T-cell activation [101].

Mouse tumor-models support the significance of cognate interactions between CD4 T cells and macrophages. In an aggressive breast tumor-mouse model IL-4-producing CD4+ T lymphocytes indirectly promoted invasion and subsequent metastasis of mammary adenocarcinomas by regulating the phenotype and effector function of tumor-associated macrophages [102]. In another study, myeloma tumors were infiltrated by macrophages within 3 days, followed by tumor-specific CD4+ Th1 cells at day 6 after which the macrophages started to kill tumor cells [103]. This indicates that during early tumor development a Th1-macrophage response controls tumor outgrowth. Thus the type of $\mathrm{T}$ cell that interacts with tumor associated APC influences the polarization and function of the APC. Depending on the type of $\mathrm{T}$ cell, APC can swap their function allowing them to suppress or to stimulate immunity and vice verse.

Studies that evaluate the type of macrophages in relation to the number and type of $\mathrm{T}$ cells in patients are scarce. In ovarian cancer high numbers of $\mathrm{B} 7 \mathrm{H} 4$ expressing immunosuppressive macrophages correlated with increased numbers of FoxP3+ T cells [30]. Accordingly, in gastrointestinal stromal tumors the number of CD163 +M2 macrophages correlated with $\mathrm{CD} 3+$ FoxP3+ regulatory cells [48]. A similar relation was reported for hepato-cholangiocarcinomas [24]. In contrast, in Hodgkin lymphoma an inverse correlation with CD68+ macrophages and FoxP3+ T cell numbers was reported. Here macrophages positively correlated with higher numbers of granzymeB and PD-1 expressing T cells instead. Alas, in this last study the type of infiltrating macrophages was not evaluated but the number of macrophages correlated to poor prognosis suggesting a M2 type of infiltration [47]. Finally, tumor-infiltrating macrophages were reported to attract IL-17+ CD4 T cells in liver carcinoma, thereby sustaining inflammation and supporting tumor promotion [104]. A recent study showed that a high number of macrophages and CD4+ $\mathrm{T}$ cells was correlated to a bad prognosis in breast carcinoma whereas CD8+ T cell dominance related to good prognosis [105]. Based on the MMTV-PyMT breast tumor mouse model, in which these authors also found a relation between macrophages, CD4 T cells and poor outcome, the CD4 T cells are likely to be Th2 cells [102]. Although these studies show that the number of infiltrating macrophages is related to the number of (regulatory) $\mathrm{T}$ cells it is not clear if these cells interact and what the outcome of interaction is with respect to macrophage function. For that the functional properties of all infiltrating $\mathrm{T}$-cell subsets should be evaluated.

\section{Repolarization of macrophages - a way to treat cancer?}

The strong infiltration of human tumors by activated CD8+ cytotoxic lymphocytes (CTL) and CD4+ helper T (Th) cells but not immune suppressive cells such as regulatory T cells, M2 macrophages and myeloid derived suppressor cells is a hallmark for improved survival after therapy (reviewed by [106]). The treatment of cancer may take advantage of therapies that interfere with M2 macrophages, if combined with standard or immunotherapeutic regimens. Therapeutic modalities may attack at several levels; the attraction, the differentiation or the activation of macrophages.

One therapeutic option is to interfere at the level of macrophage attraction and differentiation by abrogation of the PGE2, IL-6 and STAT3 activation loop. This may 
directly affect tumor growth and limit the induction of tolerogenic macrophages as well. Several trials were conducted in which PGE2 production was inhibited by blocking of the COX-2 enzyme, often in combination with standard cytotoxic therapy [90,107]. Since all studies were initiated to block the paracrine loop on tumor cells not much is documented about the immunological effects let alone macrophage differentiation. One report mentions high immune cell infiltration, including macrophages upon 3 days of treatment with the COXinhibitor [108].

A second strategy to interfere with immune cells in the tumor micro milieu is the blockade of cytokines secreted by the tumor or immune cells (e.g. M-CSF or IL-6). Recently, a phase II trial in patients with ovarian carcinoma was reported were the anti-IL-6 antibody siltuximab was tested [87]. The goal in this study was to deprive the tumor from growth factors and to prevent the differentiation of M2 macrophages. It might prove difficult to reach high enough antibody titers to block cytokine levels as macrophages tend to accumulate in poorly vascularized tumor areas [83]. Blocking of the cytokine receptors is not advised as membrane bound antibodies may activate type 2 macrophages via cross linking of the Fc $\gamma$ Receptors and thereby activate tumor promoting cascades. This was recently demonstrated in vitro for the humanized Fc region optimized antibody cetuximab that binds the EGFReceptor at the tumor cell surface and which caused activated M2 macrophages to produce IL-10 following the cross-linking of Fc-receptors [65].

All above mentioned strategies aim to inhibit the induction of M2 macrophages but do not reprogram M2 macrophages once they exist. In vitro macrophages can adapt to another phenotype upon a strong polarizing stimulus as discussed before [97]. Therefore, deliverance of a local APC-activating stimulus may be an attractive option. Macrophages highly express PAMPreceptors and several agonists for TLR and NOD-receptors are currently under clinical investigation for the treatment of cancer. For instance, easy accessible (pre-) malignancies have already been treated with TLR7 agonists [109]. We showed that activation of M2 macrophages in vitro by a number of different TLR agonist's results in the loss of expression of typical M2 markers but did not alter their typical M2 function [66]. Following this principle through made us realize that it also bears impact on other studies in this field. The group of Zitvogel extensively studied the effects of chemotherapy and showed that HMGB-1 released from dying tumor cells acted as a TLR4 agonist to activate APC [110]. The specific immune modulating properties of proteins released from dying tumor cells (e.g. HMGB-1) on the activation of M2 macrophages via PAMP-receptors is not yet studied.
Reprogramming of M2 to M1 type macrophages not only requires receptor-mediated activation signals but the presence of polarizing cytokines (e.g. IFN $\gamma$ ) as well. TLR are also expressed by $\mathrm{T}$ cells and stimulation modulates T-cell responses upon TCR triggering [111]. At the $\mathrm{T}$-cell population level this may result in the enhanced production of IFN $\gamma$ by $\mathrm{T}$ cells but also the downregulation of regulatory $\mathrm{T}$-cell function [111]. One can envisage that if TLR-agonists not only activate macrophages but also $\mathrm{T}$ cells to produce IFN $\gamma$ this will result in reprogramming of the macrophages. On the other hand, our own studies on the TLR expression by patient derived tumor-antigen-specific CD4+ T-cell clones, including helper $\mathrm{T}$ cells and regulatory $\mathrm{T}$-cell clones, revealed that human $\mathrm{T}$ cells express a number of different TLRs at the mRNA level and that the TLR expression pattern differed per CD4+ T-cell clone independent of their function. When these CD4+ T-cell clones were tested in various activation (proliferation, cytokine production) and suppression assays no consistent gain (proliferation/IFN $\gamma$ production) or loss in function was observed due to the presence of TLR-agonists either with or without TCR triggering. This suggests that TLR may not play a major role when CD4+ T cells are fully polarized already (unpublished observations). It is, therefore, questionable whether the application TLR agonists may result in repolarization of macrophages.

A recent study revealed that activation of macrophages by the infusion of antibodies against CD40 may induce macrophage-mediated tumor regression in $30 \%$ of cases in both a mouse model for pancreatic cancer and in patients with pancreatic cancer [112]. CD40 therapy resulted in the stimulation of secondary lymph node resident macrophages to migrate into the tumor tissue. Whereas, tumor-infiltrating in non-treated animals predominantly produced IL-10, the tumor-infiltrating macrophages of antibody treated mice produced IL-12 [112]. Notably, macrophages already present in the tumor were not stimulated by this treatment, possibly due to a low tissue penetration of the antibody [112]. In vitro $\mathrm{CD} 40$-activation with IFN $\gamma$ was required to effectively reprogram tumor-induced M2-like macrophages into activated IL-12 producing M1 cells (Figure 1). As CD40 is not only expressed by macrophages but also by monocytes, endothelial cells, epithelial cells, and B cells [113], it is likely that the activation of several cell types throughout the body resulted in the deliverance of the necessary pro-inflammatory cytokines that allowed the circulating CD40-activated macrophages to adapt to a M1 phenotype.

In order to reprogram macrophages directly in the tumor-microenvironment, it is essential that CD4+ Th1 cells are locally present. The capacity of tumor-specific Th1 cells to directly alter the tumor microenvironment 
has also been recognized in studies on tissue-infiltrating CD8+ T cells in mice models. Th1 cells were essential for successful recruitment, local expansion and full effector function of large numbers of CTL by modulation of the local environment $[114,115]$, and this may have included the repolarization of macrophages. In order to obtain sufficient numbers of tumor-specific CD4+ Th1 cells one may make use of adoptive T-cell transfer protocols $[116,117]$ or apply strong vaccines $[118,119]$.

\section{Conclusion and prospective}

Macrophages play an important role in tumors. Depending on the mode of activation, they may promote tumor growth and suppress local immunity or attack tumor cells and sustain tumor immunity. Immunotherapeutic strategies to combat cancer should incorporate approaches focused on the attraction and polarization of M1 macrophages as well as on the reprogramming of M2 macrophages to the M1 subset. This requires a well-based understanding of the different subsets of macrophages in human tumors as well as their interaction with other members of the immune system, including $\mathrm{T}$ helper cells. To this end, the type and numbers of macrophages in the tumor have to be more carefully analyzed by the simultaneous use of several markers that allow discriminating the different macrophages subsets in one run. New and better subset-specific markers need to be identified. In addition, it will require indepth studies on the interaction of local $\mathrm{T}$ cells and macrophages, a subject which currently is only marginally studied in human cancers.

\begin{abstract}
Abbreviations
M1: type 1 pro- inflammatory macrophage; M2: type 2 macrophage; DC: Dendritic Cell; CTL,Cytotoxic CD8+ T cell; Th: CD4+ helper T cell; ROS: reactive oxygen species (ROS); NO: Nitric Oxide; iNOS: inducible Nitric Oxide Synthase; HMGB-1,High Mobility Group protein B1; HSP: Heat Shock Protein; PAMP: Pathogen Associated Molecular Pattern; TLR: Toll Like Receptor.
\end{abstract}

\section{Acknowledgements}

This study was financially supported by a grant from the Dutch Cancer Society 2007-3848 to SHvdB

\section{Authors' contributions}

$\mathrm{MH}$ and $\mathrm{SH} v \mathrm{~dB}$ contributed equally to this manuscript. All authors read and approved the final manuscript.

\section{Competing interests}

The authors declare that they have no competing interests.

Received: 1 October 2011 Accepted: 16 December 2011 Published: 16 December 2011

\section{References}

1. Steinman RM, Idoyaga J: Features of the dendritic cell lineage. Immunol Rev 2010, 234:5-17.

2. Gordon S, Martinez FO: Alternative activation of macrophages: mechanism and functions. Immunity 2010, 32:593-604.
3. Mantovani A, Sica A: Macrophages, innate immunity and cancer: balance, tolerance, and diversity. Curr Opin Immunol 2010, 22:231-237.

4. Kreider T, Anthony RM, Urban JF Jr, Gause WC: Alternatively activated macrophages in helminth infections. Curr Opin Immunol 2007, 19:448-453.

5. Biswas SK, Mantovani A: Macrophage plasticity and interaction with lymphocyte subsets: cancer as a paradigm. Nat Immunol 2010, 11:889-896.

6. Mantovani A, Sozzani S, Locati M, Allavena P, Sica A: Macrophage polarization: tumor-associated macrophages as a paradigm for polarized M2 mononuclear phagocytes. Trends Immunol 2002, 23:549-555.

7. Mosser DM, Edwards JP: Exploring the full spectrum of macrophage activation. Nat Rev Immunol 2008, 8:958-969.

8. Stout RD, Jiang C, Matta B, Tietzel I, Watkins SK, Suttles J: Macrophages sequentially change their functional phenotype in response to changes in microenvironmental influences. J Immunol 2005, 175:342-349.

9. Qian BZ, Pollard JW: Macrophage diversity enhances tumor progression and metastasis. Cell 2010, 141:39-51.

10. Porta C, Riboldi E, Sica A: Mechanisms linking pathogens-associated inflammation and cancer. Cancer Lett 2011, 305:250-262.

11. Hanahan D, Weinberg RA: Hallmarks of cancer: the next generation. Cell 2011, 144:646-674

12. Azambuja D, Natkunam Y, Biasoli I, Lossos IS, Anderson MW, Morais JC, et al: Lack of association of tumor-associated macrophages with clinical outcome in patients with classical Hodgkin's lymphoma. Ann Oncol 2011.

13. Bailey C, Negus R, Morris A, Ziprin P, Goldin R, Allavena P, et al: Chemokine expression is associated with the accumulation of tumour associated macrophages (TAMs) and progression in human colorectal cancer. Clin Exp Metastasis 2007, 24:121-130.

14. Bronkhorst $I H$, Ly LV, Jordanova ES, Vrolijk J, Versluis $M$, Luyten GP, et al: Detection of M2-macrophages in uveal melanoma and relation with survival. Invest Ophthalmol Vis Sci 2011, 52:643-650.

15. Burt BM, Rodig SJ, Tilleman TR, Elbardissi AW, Bueno R, Sugarbaker DJ: Circulating and tumor-infiltrating myeloid cells predict survival in human pleural mesothelioma. Cancer 2011, 117:1534-1544.

16. Caillou B, Talbot M, Weyemi U, Pioche-Durieu C, Al GA, Bidart JM, et al: Tumor-associated macrophages (TAMs) form an interconnected cellular supportive network in anaplastic thyroid carcinoma. PLoS One 2011, 6: e22567.

17. Campbell MJ, Tonlaar NY, Garwood ER, Huo D, Moore DH, Khramtsov Al, et al: Proliferating macrophages associated with high grade, hormone receptor negative breast cancer and poor clinical outcome. Breast Cancer Res Treat 2011, 128:703-711.

18. Chen J, Yao Y, Gong C, Yu F, Su S, Chen J, et al: CCL18 from tumorassociated macrophages promotes breast cancer metastasis via PITPNM3. Cancer Cell 2011, 19:541-555.

19. Espinosa I, Jose CM, Catasus L, Canet B, D'angelo E, Zannoni GF, et al: Myometrial invasion and lymph node metastasis in endometrioid carcinomas: tumor-associated macrophages, microvessel density, and HIF1A have a crucial role. Am J Surg Pathol 2010, 34:1708-1714.

20. Figel AM, Brech D, Prinz PU, Lettenmeyer UK, Eckl J, Turqueti-Neves A, et al: Human renal cell carcinoma induces a dendritic cell subset that uses Tcell crosstalk for tumor-permissive milieu alterations. Am J Pathol 2011, 179:436-451.

21. Forssell J, Oberg A, Henriksson ML, Stenling R, Jung A, Palmqvist R: High macrophage infiltration along the tumor front correlates with improved survival in colon cancer. Clin Cancer Res 2007, 13:1472-1479.

22. Freedman RS, Wang E, Voiculescu S, Patenia R, Bassett RL Jr, Deavers M, et al: Comparative analysis of peritoneum and tumor eicosanoids and pathways in advanced ovarian cancer. Clin Cancer Res 2007, 13:5736-5744.

23. Hammes LS, Tekmal RR, Naud P, Edelweiss MI, Kirma N, Valente PT, et al: Macrophages, inflammation and risk of cervical intraepithelial neoplasia (CIN) progression-clinicopathological correlation. Gynecol Oncol 2007, 105:157-165.

24. Hasita H, Komohara Y, Okabe H, Masuda T, Ohnishi K, Lei XF, et al: Significance of alternatively activated macrophages in patients with intrahepatic cholangiocarcinoma. Cancer Sci 2010, 101:1913-1919.

25. Jensen TO, Schmidt H, Moller HJ, Hoyer M, Maniecki MB, Sjoegren P, et al: Macrophage markers in serum and tumor have prognostic impact in American Joint Committee on Cancer stage I/II melanoma. J Clin Oncol 2009, 27:3330-3337. 
26. Kang JC, Chen JS, Lee CH, Chang JJ, Shieh YS: Intratumoral macrophage counts correlate with tumor progression in colorectal cancer. J Surg Oncol 2010, 102:242-248.

27. Kawamura K, Komohara Y, Takaishi K, Katabuchi H, Takeya M: Detection of M2 macrophages and colony-stimulating factor 1 expression in serous and mucinous ovarian epithelial tumors. Pathol Int 2009, 59:300-305.

28. Komohara Y, Ohnishi K, Kuratsu J, Takeya M: Possible involvement of the M2 anti-inflammatory macrophage phenotype in growth of human gliomas. J Pathol 2008, 216:15-24

29. Kryczek I, Zou L, Rodriguez P, Zhu G, Wei S, Mottram P, et al: B7-H4 expression identifies a novel suppressive macrophage population in human ovarian carcinoma. J Exp Med 2006, 203:871-881.

30. Kryczek I, Wei S, Zhu G, Myers L, Mottram P, Cheng P, et al: Relationship between $\mathrm{B} 7-\mathrm{H} 4$, regulatory $\mathrm{T}$ cells, and patient outcome in human ovarian carcinoma. Cancer Res 2007, 67:8900-8905.

31. Kurahara $H$, Shinchi $H$, Mataki $Y$, Maemura K, Noma H, Kubo F, et al: Significance of M2-polarized tumor-associated macrophage in pancreatic cancer. J Surg Res 2011, 167:e211-e219.

32. Lee CH, Espinosa I, Vrijaldenhoven S, Subramanian S, Montgomery KD, Zhu $\mathrm{S}$, et al: Prognostic significance of macrophage infiltration in leiomyosarcomas. Clin Cancer Res 2008, 14:1423-1430.

33. Ma J, Liu L, Che G, Yu N, Dai F, You Z: The M1 form of tumor-associated macrophages in non-small cell lung cancer is positively associated with survival time. BMC Cancer 2010, 10:112.

34. Nagorsen D, Voigt S, Berg E, Stein H, Thiel E, Loddenkemper C: Tumorinfiltrating macrophages and dendritic cells in human colorectal cancer: relation to local regulatory $\mathrm{T}$ cells, systemic T-cell response against tumor-associated antigens and survival. J Transl Med 2007, 5:62.

35. Niino D, Komohara Y, Murayama T, Aoki R, Kimura Y, Hashikawa K, et al: Ratio of M2 macrophage expression is closely associated with poor prognosis for Angioimmunoblastic T-cell lymphoma (AITL). Pathol Int 2010, 60:278-283.

36. Nonomura N, Takayama H, Nakayama M, Nakai Y, Kawashima A, Mukai M, et al: Infiltration of tumour-associated macrophages in prostate biopsy specimens is predictive of disease progression after hormonal therapy for prostate cancer. BJU Int 2011, 107:1918-1922.

37. Ohri CM, Shikotra A, Green RH, Waller DA, Bradding P: Macrophages within NSCLC tumour islets are predominantly of a cytotoxic M1 phenotype associated with extended survival. Eur Respir J 2009, 33:118-126.

38. Ohri CM, Shikotra A, Green RH, Waller DA, Bradding P: Chemokine receptor expression in tumour islets and stroma in non-small cell lung cancer. BMC Cancer 2010, 10:172.

39. Osinsky S, Bubnovskaya L, Ganusevich I, Kovelskaya A, Gumenyuk L, Olijnichenko G, et al: Hypoxia, tumour-associated macrophages, microvessel density, VEGF and matrix metalloproteinases in human gastric cancer: interaction and impact on survival. Clin Transl Oncol 2011, 13:133-138.

40. Rigo A, Gottardi M, Zamo A, Mauri P, Bonifacio M, Krampera M, et al: Macrophages may promote cancer growth via a GM-CSF/HB-EGF paracrine loop that is enhanced by CXCL12. Mol Cancer 2010, 9:273.

41. Ryder M, Ghossein RA, Ricarte-Filho JC, Knauf JA, Fagin JA: Increased density of tumor-associated macrophages is associated with decreased survival in advanced thyroid cancer. Endocr Relat Cancer 2008, 15:1069-1074

42. Sanchez-Martin L, Estecha A, Samaniego R, Sanchez-Ramon S, Vega MA, Sanchez-Mateos P: The chemokine CXCL12 regulates monocytemacrophage differentiation and RUNX3 expression. Blood 2011, 117:88-97

43. Shabo I, Stal O, Olsson H, Dore S, Svanvik J: Breast cancer expression of CD163, a macrophage scavenger receptor, is related to early distant recurrence and reduced patient survival. Int J Cancer 2008, 123:780-786.

44. Shieh YS, Hung YJ, Hsieh CB, Chen JS, Chou KC, Liu SY: Tumor-associated macrophage correlated with angiogenesis and progression of mucoepidermoid carcinoma of salivary glands. Ann Surg Oncol 2009, 16:751-760.

45. Steidl C, Lee T, Shah SP, Farinha P, Han G, Nayar T, et al: Tumor-associated macrophages and survival in classic Hodgkin's lymphoma. N Engl J Med 2010, 362:875-885.

46. Takayama H, Nonomura N, Nishimura K, Oka D, Shiba M, Nakai Y, et al: Decreased immunostaining for macrophage scavenger receptor is associated with poor prognosis of prostate cancer. BJU Int 2009, 103:470-474.

47. Tzankov A, Matter MS, Dirnhofer S: Refined prognostic role of CD68 positive tumor macrophages in the context of the cellular micromilieu of classical Hodgkin lymphoma. Pathobiology 2010, 77:301-308.

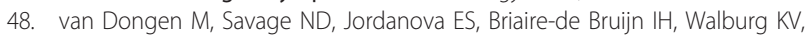
Ottenhoff TH, et al: Anti-inflammatory M2 type macrophages characterize metastasized and tyrosine kinase inhibitor-treated gastrointestinal stromal tumors. Int J Cancer 2010, 127:899-909.

49. Webster JA, Beck AH, Sharma M, Espinosa I, Weigelt B, Schreuder M, et al: Variations in stromal signatures in breast and colorectal cancer metastases. J Pathol 2010, 222:158-165.

50. Yang $X$, Dong $Y$, Zhao J, Sun H, Deng $Y$, Fan J, et al: Increased expression of human macrophage metalloelastase (MMP-12) is associated with the invasion of endometrial adenocarcinoma. Pathol Res Pract 2007, 203:499-505.

51. Zeni E, Mazzetti L, Miotto D, Lo CN, Maestrelli P, Querzoli P, et al: Macrophage expression of interleukin-10 is a prognostic factor in nonsmall cell lung cancer. Eur Respir J 2007, 30:627-632.

52. Algars A, Irjala H, Vaittinen S, Huhtinen H, Sundstrom J, Salmi M, et al: Type and location of tumor-infiltrating macrophages and lymphatic vessels predict survival of colorectal cancer patients. Int J Cancer 2011.

53. Bingle L, Brown NJ, Lewis CE: The role of tumour-associated macrophages in tumour progression: implications for new anticancer therapies. $J$ Pathol 2002, 196:254-265.

54. Zijlmans HJ, Fleuren GJ, Baelde HJ, Eilers PH, Kenter GG, Gorter A: Role of tumor-derived proinflammatory cytokines GM-CSF, TNF-alpha, and IL-12 in the migration and differentiation of antigen-presenting cells in cervical carcinoma. Cancer 2007, 109:556-565.

55. Kuang DM, Wu Y, Chen N, Cheng J, Zhuang SM, Zheng L: Tumor-derived hyaluronan induces formation of immunosuppressive macrophages through transient early activation of monocytes. Blood 2007, 110:587-595.

56. Movahedi K, Laoui D, Gysemans C, Baeten M, Stange G, Van den Bossche J, et al: Different tumor microenvironments contain functionally distinct subsets of macrophages derived from Ly6C(high) monocytes. Cancer Res 2010, 70:5728-5739.

57. Pettersen JS, Fuentes-Duculan J, Suarez-Farinas M, Pierson KC, Pitts-Kiefer A, Fan $L$, et al: Tumor-associated macrophages in the cutaneous SCC microenvironment are heterogeneously activated. J Invest Dermatol 2011, 131:1322-1330

58. Gadiot J, Hooijkaas Al, Kaiser AD, van TH, van BH, Blank C: Overall survival and PD-L1 expression in metastasized malignant melanoma. Cancer 2011, 117:2192-2201

59. Karim R, Jordanova ES, Piersma SJ, Kenter GG, Chen L, Boer JM, et al: Tumor-expressed $\mathrm{B} 7-\mathrm{H} 1$ and $\mathrm{B} 7-\mathrm{DC}$ in relation to $\mathrm{PD}-1+\mathrm{T}$-cell infiltration and survival of patients with cervical carcinoma. Clin Cancer Res 2009, 15:6341-6347.

60. McLean MH, Murray Gl, Stewart KN, Norrie G, Mayer C, Hold GL, et al: The inflammatory microenvironment in colorectal neoplasia. PLOS One 2011, 6:e15366.

61. Piersma SJ, Jordanova ES, van Poelgeest MI, Kwappenberg KM, van der Hulst JM, Drijfhout JW, et al: High number of intraepithelial CD8+ tumorinfiltrating lymphocytes is associated with the absence of lymph node metastases in patients with large early-stage cervical cancer. Cancer Res 2007, 67:354-361.

62. Curiel TJ, Coukos G, Zou L, Alvarez X, Cheng P, Mottram P, et al: Specific recruitment of regulatory $T$ cells in ovarian carcinoma fosters immune privilege and predicts reduced survival. Nat Med 2004, 10:942-949.

63. Jordanova ES, Gorter A, Ayachi O, Prins F, Durrant LG, Kenter GG, et al: Human leukocyte antigen class I, MHC class I chain-related molecule A and CD8+/regulatory T-cell ratio: which variable determines survival of cervical cancer patients? Clin Cancer Res 2008, 14:2028-2035.

64. Takahashi A, Kono K, Ichihara F, Sugai H, Amemiya H, lizuka H, et al: Macrophages in tumor-draining lymph node with different characteristics induce T-cell apoptosis in patients with advanced stagegastric cancer. Int J Cancer 2003, 104:393-399.

65. Pander J, Heusinkveld M, van der Straaten T, Jordanova ES, Baak-Pablo R, Gelderblom H, et al: Activation of Tumor-Promoting Type 2 Macrophages by EGFR-Targeting Antibody Cetuximab. Clin Cancer Res 2011, 17:5668-5673. 
66. Heusinkveld M, de Vos van Steenwijk PJ, Goedemans R Ramwadhdoebe TH, Gorter A, Welters MJ, et al: M2 macrophages induced by prostaglandin E2 and IL- 6 from cervical carcinoma are switched to activated M1 macrophages by CD4+ Th1 cells. J Immunol 2011, 187:1157-1165.

67. Verreck FA, de BT, Langenberg DM, van der Zanden L, Ottenhoff TH: Phenotypic and functional profiling of human proinflammatory type-1 and anti-inflammatory type- 2 macrophages in response to microbial antigens and IFN-gamma- and CD40L-mediated costimulation. J Leukoc Biol 2006, 79:285-293

68. Maniecki MB, Etzerodt A, Moestrup SK, Moller HJ, Graversen JH: Comparative assessment of the recognition of domain-specific CD163 monoclonal antibodies in human monocytes explains wide discrepancy in reported levels of cellular surface CD163 expression. Immunobiology 2011, 216:882-890

69. Mantovani A, Sica A, Allavena P, Garlanda C, Locati M: Tumor-associated macrophages and the related myeloid-derived suppressor cells as a paradigm of the diversity of macrophage activation. Hum Immunol 2009, 70:325-330.

70. Martin MD, Matrisian LM: The other side of MMPs: protective roles in tumor progression. Cancer Metastasis Rev 2007, 26:717-724.

71. Martinez FO, Gordon S, Locati M, Mantovani A: Transcriptional profiling of the human monocyte-to-macrophage differentiation and polarization: new molecules and patterns of gene expression. J Immunol 2006, 177:7303-7311.

72. Murray PJ, Wynn TA: Obstacles and opportunities for understanding macrophage polarization. J Leukoc Biol 2011, 89:557-563.

73. Pilling D, Fan T, Huang D, Kaul B, Gomer RH: Identification of markers that distinguish monocyte-derived fibrocytes from monocytes, macrophages, and fibroblasts. PLoS One 2009, 4:e7475.

74. Puig-Kroger A, Sierra-Filardi E, Dominguez-Soto A, Samaniego R, Corcuera MT, Gomez-Aguado F, et al: Folate receptor beta is expressed by tumor-associated macrophages and constitutes a marker for $\mathrm{M} 2$ antiinflammatory/regulatory macrophages. Cancer Res 2009, 69:9395-9403.

75. Van Gorp H, Delputte PL, Nauwynck HJ: Scavenger receptor CD163, a Jack-of-all-trades and potential target for cell-directed therapy. $\mathrm{Mol}$ Immunol 2010, 47:1650-1660.

76. Xu W, Schlagwein N, Roos A, van den Berg TK, Daha MR, van KC: Human peritoneal macrophages show functional characteristics of M-CSF-driven anti-inflammatory type 2 macrophages. Eur J Immunol 2007, 37:1594-1599.

77. Yu H, Pardoll D, Jove R: STATs in cancer inflammation and immunity: a leading role for STAT3. Nat Rev Cancer 2009, 9:798-809.

78. Avila-Moreno F, Lopez-Gonzalez JS, Galindo-Rodriguez G, Prado-Garcia H, Bajana S, Sanchez-Torres C: Lung squamous cell carcinoma and adenocarcinoma cell lines use different mediators to induce comparable phenotypic and functional changes in human monocyte-derived dendritic cells. Cancer Immunol Immunother 2006, 55:598-611.

79. Duluc D, Delneste Y, Tan F, Moles MP, Grimaud L, Lenoir J, et al: Tumorassociated leukemia inhibitory factor and IL-6 skew monocyte differentiation into tumor-associated macrophage-like cells. Blood 2007, 110:4319-4330.

80. Lawrence T, Natoli G: Transcriptional regulation of macrophage polarization: enabling diversity with identity. Nat Rev Immunol 2011 11:750-761.

81. Krausgruber T, Blazek K, Smallie T, Alzabin S, Lockstone H, Sahgal N, et al: IRF5 promotes inflammatory macrophage polarization and TH1-TH17 responses. Nat Immunol 2011, 12:231-238.

82. Martinez FO: Regulators of macrophage activation. Eur J Immunol 2011, 41:1531-1534.

83. Murdoch C, Giannoudis A, Lewis CE: Mechanisms regulating the recruitment of macrophages into hypoxic areas of tumors and other ischemic tissues. Blood 2004, 104:2224-2234.

84. Roca H, Varsos ZS, Sud S, Craig MJ, Ying C, Pienta KJ: CCL2 and interleukin6 promote survival of human $\mathrm{CD} 11 \mathrm{~b}+$ peripheral blood mononuclear cells and induce M2-type macrophage polarization. J Biol Chem 2009, 284:34342-34354.

85. Zhang J, Patel L, Pienta KJ: CC chemokine ligand 2 (CCL2) promotes prostate cancer tumorigenesis and metastasis. Cytokine Growth Factor Rev 2010, 21:41-48.
86. Choy E: Inhibiting interleukin-6 in rheumatoid arthritis. Curr Rheumatol Rep 2008, 10:413-417.

87. Coward J, Kulbe H, Chakravarty P, Leader D, Vassileva V, Leinster DA, et al: Interleukin-6 as a Therapeutic Target in Human Ovarian Cancer. Clin Cancer Res 2011, 17:6083-6096.

88. Gabrilovich DI, Chen HL, Girgis KR, Cunningham HT, Meny GM, Nadaf S, et al: Production of vascular endothelial growth factor by human tumors inhibits the functional maturation of dendritic cells. Nat Med 1996, 2:1096-1103.

89. Wang D, Dubois RN: Eicosanoids and cancer. Nat Rev Cancer 2010, 10:181-193.

90. Brown JR, Dubois RN: COX-2: a molecular target for colorectal cancer prevention. J Clin Oncol 2005, 23:2840-2855.

91. Herfs M, Herman L, Hubert P, Minner F, Arafa M, Roncarati P, et al: High expression of PGE2 enzymatic pathways in cervical (pre)neoplastic lesions and functional consequences for antigen-presenting cells. Cancer Immunol Immunother 2009, 58:603-614.

92. Obermajer N, Muthuswamy R, Lesnock J, Edwards RP, Kalinski P: Positive feedback between PGE2 and COX2 redirects the differentiation of human dendritic cells toward stable myeloid-derived suppressor cells. Blood 2011, 118:5498-5505

93. Dalwadi H, Krysan K, Heuze-Vourc'h N, Dohadwala M, Elashoff D, Sharma S, et al: Cyclooxygenase-2-dependent activation of signal transducer and activator of transcription 3 by interleukin- 6 in non-small cell lung cancer. Clin Cancer Res 2005, 11:7674-7682.

94. Schmitt E, Gehrmann M, Brunet M, Multhoff G, Garrido C: Intracellular and extracellular functions of heat shock proteins: repercussions in cancer therapy. J Leukoc Biol 2007, 81:15-27.

95. Banerjee S, Lin CF, Skinner KA, Schiffhauer LM, Peacock J, Hicks DG, et al: Heat shock protein 27 differentiates tolerogenic macrophages that may support human breast cancer progression. Cancer Res 2011, 71:318-327.

96. Stout RD, Suttles J: Functional plasticity of macrophages: reversible adaptation to changing microenvironments. J Leukoc Biol 2004, 76:509-513.

97. Porcheray F, Viaud S, Rimaniol AC, Leone C, Samah B, DereuddreBosquet $N$, et al: Macrophage activation switching: an asset for the resolution of inflammation. Clin Exp Immunol 2005, 142:481-489.

98. Mailliard RB, Egawa S, Cai Q, Kalinska A, Bykovskaya SN, Lotze MT, et al: Complementary dendritic cell-activating function of CD8+ and CD4+ T cells: helper role of CD8+ T cells in the development of $T$ helper type 1 responses. J Exp Med 2002, 195:473-483.

99. Wirths S, Reichert J, Grunebach F, Brossart P: Activated CD8+ T lymphocytes induce differentiation of monocytes to dendritic cells and restore the stimulatory capacity of interleukin 10-treated antigenpresenting cells. Cancer Res 2002, 62:5065-5068.

100. de Vos van Steenwijk PJ, Heusinkveld M, Ramwadhdoebe TH, Lowik MJ, van der Hulst JM, Goedemans R, et al: An unexpectedly large polyclonal repertoire of HPV-specific T cells is poised for action in patients with cervical cancer. Cancer Res 2010, 70:2707-2717.

101. Tiemessen MM, Jagger AL, Evans HG, van Herwijnen MJ, John S, Taams LS CD4+CD25+Foxp3+ regulatory $T$ cells induce alternative activation of human monocytes/macrophages. Proc Natl Acad Sci USA 2007, 104:19446-19451.

102. DeNardo DG, Barreto JB, Andreu P, Vasquez L, Tawfik D, Kolhatkar N, et al: CD4(+) T cells regulate pulmonary metastasis of mammary carcinomas by enhancing protumor properties of macrophages. Cancer Cell 2009, 16:91-102

103. Corthay A, Skovseth DK, Lundin KU, Rosjo E, Omholt H, Hofgaard PO, et al: Primary antitumor immune response mediated by CD4+ T cells. Immunity 2005, 22:371-383.

104. Kuang DM, Peng C, Zhao Q, Wu Y, Chen MS, Zheng L: Activated monocytes in peritumoral stroma of hepatocellular carcinoma promote expansion of memory T helper 17 cells. Hepatology 2010, 51:154-164.

105. DeNardo DG, Brennan DJ, Rexhepaj E, Ruffell B, Shiao SL, Madden SF, et al Leukocyte Complexity Predicts Breast Cancer Survival and Functionally Regulates Response to Chemotherapy. Cancer Discovery 2011.

106. Pages F, Galon J, Dieu-Nosjean MC, Tartour E, Sautes-Fridman C, Fridman WH: Immune infiltration in human tumors: a prognostic factor that should not be ignored. Oncogene 2010, 29:1093-1102.

107. Edelman MJ, Watson D, Wang X, Morrison C, Kratzke RA, Jewell S, et al: Eicosanoid modulation in advanced lung cancer: cyclooxygenase-2 
expression is a positive predictive factor for celecoxib + chemotherapyCancer and Leukemia Group B Trial 30203. J Clin Oncol 2008, 26:848-855.

108. Lonnroth C, Andersson M, Arvidsson A, Nordgren S, Brevinge H, Lagerstedt $K$, et al: Preoperative treatment with a non-steroidal antiinflammatory drug (NSAID) increases tumor tissue infiltration of seemingly activated immune cells in colorectal cancer. Cancer Immun 2008, 8:5.

109. Terlou A, van SM, Kleinjan A, Heijmans-Antonissen C, Santegoets LA, Beckmann I, et al: Imiquimod-induced clearance of HPV is associated with normalization of immune cell counts in usual type vulvar intraepithelial neoplasia. Int I Cancer 2010, 127:2831-2840.

110. Apetoh L, Ghiringhelli F, Tesniere A, Obeid M, Ortiz C, Criollo A, et al: Tolllike receptor 4-dependent contribution of the immune system to anticancer chemotherapy and radiotherapy. Nat Med 2007, 13:1050-1059.

111. Kabelitz D: Expression and function of Toll-like receptors in T lymphocytes. Curr Opin Immunol 2007, 19:39-45.

112. Beatty GL, Chiorean EG, Fishman MP, Saboury B, Teitelbaum UR, Sun W, et al: CD40 agonists alter tumor stroma and show efficacy against pancreatic carcinoma in mice and humans. Science 2011, 331:1612-1616.

113. van Kooten C, Banchereau J: CD40-CD40 ligand. J Leukoc Biol 2000, 67:2-17.

114. Bos R, Sherman LA: CD4+ T-cell help in the tumor milieu is required for recruitment and cytolytic function of CD8+ T lymphocytes. Cancer Res 2010, 70:8368-8377.

115. Nakanishi Y, Lu B, Gerard C, Iwasaki A: CD8(+) T lymphocyte mobilization to virus-infected tissue requires CD4(+) T-cell help. Nature 2009, 462:510-513.

116. Hunder NN, Wallen H, Cao J, Hendricks DW, Reilly JZ, Rodmyre R, et al: Treatment of metastatic melanoma with autologous CD4+ T cells against NY-ESO-1. N Engl J Med 2008, 358:2698-2703.

117. Verdegaal EM, Visser M, Ramwadhdoebe $T H$, van der Minne $C E$, van Steijn JA, Kapiteijn E, et al: Successful treatment of metastatic melanoma by adoptive transfer of blood-derived polyclonal tumor-specific CD4+ and CD8+ T cells in combination with low-dose interferon-alpha. Cancer Immunol Immunother 2011, 60:953-963.

118. Melief CJ, van der Burg SH: Immunotherapy of established (pre)malignant disease by synthetic long peptide vaccines. Nat Rev Cancer 2008, 8:351-360.

119. Welters MJ, Kenter GG, de Vos van Steenwijk PJ, Lowik MJ, Berends-van der Meer DM, Essahsah F, et al: Success or failure of vaccination for HPV16positive vulvar lesions correlates with kinetics and phenotype of induced T-cell responses. Proc Natl Acad Sci USA 2010, 107:11895-11899.

doi:10.1186/1479-5876-9-216

Cite this article as: Heusinkveld and van der Burg: Identification and manipulation of tumor associated macrophages in human cancers. Journal of Translational Medicine 2011 9:216.

\section{Submit your next manuscript to BioMed Central and take full advantage of:}

- Convenient online submission

- Thorough peer review

- No space constraints or color figure charges

- Immediate publication on acceptance

- Inclusion in PubMed, CAS, Scopus and Google Scholar

- Research which is freely available for redistribution 